\title{
Challenges and Opportunities to Sustainable Sport Tourism Events: Insights from an Urban Host City
}

\author{
Ms. Lilian Wanyonyi ${ }^{1} \quad$ Dr. Joseph M.Njoroge ${ }^{2} \quad$ Prof.Richard Juma $^{3}$ \\ 1. School of Tourism and Hospitality Management, Murang’a University Technology P.O BOX 75, Murang'a \\ Kenya \\ 2. School of Tourism and Hospitality Management, Murang'a University Technology P.O BOX 75, Murang'a \\ Kenya \\ 3. School of Tourism and Hospitality Management, Murang'a University Technology P.O BOX 75, Murang'a \\ Kenya \\ Email of the corresponding author:wanyonyil@ymail.com
}

\begin{abstract}
Sports tourism is viewed as an ideal tool for supporting the livelihood of the host communities in developing countries. As an alternative way of involving the host community in tourism activities, sports tourism aims to enable the hosts to earn income from tourism. Sports tourism events have been hosted in the country for decades but still facing challenges that has hauled its growth process. This article will shade light on the challenges and opportunities of hosting sports tourism in Nairobi as a way of enhancing sustainable tourism development. A cross-sectional research design is used in the study, 404 respondents form the sample size of the study. Questionnaires and interviews are used to collect data from informants in three stadia that frequently host sports tourism events. Descriptive, thematic analysis and inferential statistics are used for data analysis. Findings indicate that major challenges facing the hosting of sports tourism event are; poor planning, policy issues and security. Results also show that the main opportunities for sports tourism events are boosting of domestic tourism, diversification of tourism products and marketing of host cities. Key recommendations are made to policy makers to craft policies that will spur sustainable sports tourism development.
\end{abstract}

Key words Sports Tourism Events, Challenges, Opportunities, Sustainable, and community

DOI: $10.7176 / \mathrm{JTHS} / 55-06$

Publication date:March $31^{\text {st }} 2021$

\section{Introduction}

The travel and tourism industry is among the highly developing sectors in the world experiencing a growth in tourists' numbers, huge employment opportunities and huge investments. WTTC, (2018) established that, the travel and tourism industry brought US $\$ 8.8$ trillion to the economy worldwide this equating to $10.4 \%$ of global GDP.It contributes to more than 319 million jobs annually, representing $10.0 \%$ of all employment worldwide. In most developing nations, it has turned out to be a major driver of social and economic progress. Tourism contributes about $10 \%$ of the Gross Domestic Product in the country each year, (KIPPRA Report, 2018). Tourism arrivals in 2018 were recorded at 2,029,206 and Ksh.157.b tourism receipts (KTB report, 2018) thus making the tourism industry a major backbone of its economy.

In its Vision 2030 blueprint, tourism in Kenya is a major pillar that the government has prioritized as a way of alleviating the poverty index and providing economic growth. The country aims to focus on niche tourism products to be among the leading destinations globally providing quality, diversified and unique tourists' experiences than her competitors GOK, (2008).To achieve this, the country has come up with different development projects among them the launching of Kenya National Tourism Blueprint 2030 that has strategies on product diversification to boost its tourism profile globally and the initiative to build state of the art stadia across the country that will boost Kenya's ability to bid and host regional and international sports tourism events. This will be a focal point in improving the quality of lives for the local people. (GoK, 2013)

Despite Kenya having an active tourism industry, 36.1\% of Kenyans live below the international poverty line with $73.9 \%$ of tourists over-relying on safari and beach tourism for their holidays which are active only in certain circuits. Sports tourism has remained the least explored segment of tourism (Njoroge, Akama \& Buyeke 2015).Sports tourism has a great potential in fostering socio-economic developments in different counties. The country has been so active in hosting and participating in different sports locally, regionally and internationally that has given Kenya a distinct recognition. In spite of this efforts, the county still suffers from myriads of challenges that has affected its progress in bidding to host major sports events for instance AFCON,Olympics 
and FIFA World cup that comes with great legacies to the host cities. The article endeavored to look at the challenges of hosting sports tourism events in Kenya and the opportunities that hosting sports tourism events can create to the host community.

Nairobi County is a hub of tourism in Africa. The county is enriched with both cultural and natural tourism attractions such as Mamba Village, Karen Blixen Museum Nairobi National Park, Giraffe Centre and Bomas of Kenya. Since the inception of devolution in 2010, the county has bidded and hosted some spectacular sporting events which include; the annual Rugby Safaricom Safari Sevens Series, IAAF World under 18 Championships, AFCON qualifiers championships, African Volleyball Championships, Ice Stock Sports Africa, WRC Safari Rally, East Africa military games and African Deaf Athletics Championships. The city has several stadia that host different events which have made the city ideal for sports participants and fans. For instance Moi International Sports Complex, Nyayo stadium and Nairobi City Stadium.

Despite this, there are several challenges that developing countries like Kenya go through in order to host successful events. Firstly, insufficient funding has been identified as the main problem hindering most developing countries, including Kenya, from hosting major sports events (Andreff, 2012, Odhiambo, 2015). In Africa, sports is considered as an activity that is recreational and meant for luxury, therefore government funding is given to priority areas like health, education and agriculture as a way of meeting the SDGs (Obonyo, 2013).Secondly, corruption and embezzlement of sports finds have been greatly hit the process of bidding and planning of events whenever the bids become successful. (AfriCOG, 2011).Thirdly, though the main motivation of hosting sports tourism events in developing nations is for growth reasons, the lack of strategic tourism planning and policies has altered the growth of tourism in Nairobi.(Njoroge, Akama \&Buyeke 2015). Developing countries have active and strong sports tourism policies that guides their bidding process. This has made its bidding process more reliable and convenient. Asian, African and South American countries have been denied or locked out of hosting due to weak or non-existing sports policies. This doesn't give them give them bidding guidelines to adhered to when hosting these events. Lastly, security concerns is a major priority when hosting events, as participants and fans care a lot for their safety and security whenever events are hosted in different countries or cities. For instance, Libya could not host the AFCON in 2013 as a result of civil wars hence the event was moved to South Africa(Auer (2014) in 2011 it also withdrew its bid for hosting of 2017 African Cup of Nations. It is against this basis that the study will endeavor to look at some of the challenges that may face Kenya's capacity to bid for sports tourism events and the opportunities they bring.

\subsection{Devolution and growth of sports events tourism in Kenya}

Devolution refers to a decentralization of political powers and economic resources to the local divisions. The Kenyan Constitution in 2010 enshrined devolution. The constitution enabled the formation of forty-seven counties that are governed independently (Khaunya, Wawire \& Chepng 'eno, 2015). County governments have continued to strive towards promoting economic welfare to improve the GDP of the country. According World Bank report (2019), county governments contribute 5.7\% of the overall GDP in the country. Tourism is among the sectors that have attracted the attention of these devolved units as they have realized the benefits of promoting tourism. Devolution has opened ways for many county governments because it provides a way of getting enjoying the tourism benefits from their interactions with the tourists.

According to Chalip (2015), Sport tourism has opened up spaces in rural development. In the case of Kenya, devolution has opened up remote places through equitable allocation of resources to the county. Counties have dockets for tourism that is responsible for mapping of tourism resources, tourism product development and marketing. As a way of diversifying their tourism products, some counties have been at the forefront of developing sports facilities that have made them host spectacular sports events. Njoroge, Atieno and Nacimendo (2017) pointed out that, with a centralized system of governance, tourism developments in some parts of Kenya were disregarded as priority was given to the coastal region because of the serene beaches and wildlife. However, these led to a lack of diversification in tourism products offered by the country. They further explained that the counties have led to the development of new destinations with diverse tourism products which have enabled the country to curb seasonality which was majorly caused by overreliance on beach and wildlife tourism. In this perspective, sports tourism has remained an important pillar in some counties like Machakos and Nairobi. Additionally, the authors note that there is limited studies linking sports and tourism in counties despite the inception of devolution in the country. (Njoroge et al, 2017)

\subsection{Policy and Hosting of sports tourism}

Sports policies are formulated and used by sports governing bodies, governments and sports clubs to propel their sporting activities in their countries. King (2009) and Herbold, Thees and Philipp (2020) assert that these policies are enacted to deal with a given problem or situation. Many countries across the world have come up 
successfully with sports tourism policies that have aided in the bidding and hosting of events. For instance, countries like Canada have come up with various policies that have made them host different international events that have not only given them international recognition but also made them make some milestones in terms of sports tourism. Canadian Heritage has worked with the provinces, territories and the sport community to come up with a Federal Policy for Hosting International Sport Events. The country successfully bidded to host events like World Police \& Fire Games, FIS Snowboard World Cup, World Wheelchair Rugby and Olympics.

Despite Kenya taking part in international events as early as 1950s, the Department of sports was established years later after independence in 1988.In 2013, the country enacted its very first sports Act which was an outcome of Kenya National Sports Policy that was started way back in 2002 to offer a guideline on sports management in the country. This was caused by the previous management issues, financial misappropriations and wrangles in succession in Sports Ministry and federation. Sports federations such as Athletic Kenya, Kenya Football Federation, Kenya Hockey Union, Kenya Rugby Union, and Cricket Kenya have encountered wrangles on their management that have affected their participation in events and withdrawal of sponsors. (GOK, 2012).

As a result of the stated issues, the Ministry of Sports and Culture commenced the policy formulation process to curb the ministry from such challenges. The policy was benchmarked to that of other countries like South Africa, the UK and Australia because of their admirable performance in sports, facilities and strong existing policies. The Sports Act allowed the formation of sports institutions like Sports Kenya, Kenya Academy of Sports, Sports Fund, the Sports Disputes Tribunal and Sports Registrar office .Sports Kenya was mandated with key functions like facilitating the preparation and participation of Kenyan teams in various international events and the hosting of similar events in the country, promoting, coordinating and implementing national and international sports programs for Kenyans in liaison with the relevant sports organizations, managing and maintaining the sports facilities, promoting of sports tourism and collaborating with county governments, learning institutions and other stakeholders concerned with sports and recreation. Apart from illustrating the institutions, the requirements of the office holders, the Sports Act also outlines the rules and regulations of conducting business among those institutions in the Act and offences and penalties that will be accorded to those who go against it. Compared to the Sports Act, the Sports Policy was more detailed explaining what is to be expected in the management of sports in the country (Kenya Law, 2013)

Despite the formulation of the Sports Act, Kenya lacks an established policy on hosting international, regional or national sports tourism events. The sports act seems to be silent on the issue of hosting sports tourism events and the national federations do not comprehend their expectations on hosting. The guidelines followed during hosting involve the formation of ad-hoc committees which are disbanded after the event as there is no specific division or department within the ministry in charge of hosting for these events (Odhiambo, 2015)

Kenya lacks sports event hosting policy, which gives guidelines on hosting sports events (McCloy, 2009). The policy is useful in guiding the government and the federations on which events are to be funded by the government and the amount to be given by the government. Having an official policy for hosting major sports events is vital on making a decision for bidding to host an event. This further allow a region, city or nation to bid for certain types of events strategically in line with their objectives and goals.

\subsection{The Covid 19 pandemic and its effects on sports tourism}

Sports tourism has been recognized as rapidly growing form of tourism worldwide. Hosting of sports tourism events enables cities or regions to promote their destinations and to diversify its products. Events also exposes the host destination to the world and stimulates the host community's economy (Bennekom, (2014),Maditinos,Vassiliadis, Tzavlopous \&Vassiliadis(2020) In 2020, the outbreak of Covid 19 disease from China brought the entire world to a halt .This was followed by numerous unfrequented effects that affected different sectors of economy. The health and safety measures and restrictions affected all spheres of life. Sports tourism being a multi-million dollar industry was not an exceptional. The rising rates of infection in different countries brought diversified containment measures such as travel restrictions and lock downs that led to postponing or cancelling of many sports tourism events. The pandemic, which is characterized as one of the more significant human experiences of the twenty-first century (Galvani, Lew and Perez (2020), has caused the most significant disruption to the worldwide sporting calendar. The Tokyo Olympics were postponed until 2021, World Championships, and World Cups for virtually every sport have been cancelled or postponed and the calendars for most major sports have been severely disrupted with no clear indication yet of how or when this will be resolved. According to UNWTO report, (2020), tourism industry estimated a loss of approximately 1.1 billion international tourist arrivals, with a loss of US\$ 910 to 1.1 trillion export revenues and 100-120 million jobs due to the wider spread of the novel coronavirus. Similarly in Kenya, the pandemic has led to postponing of 
mega events like the annual Magical Kenya Golf championships. The pandemic has affected the sports tourism demand and supply chains in major host destinations. For instance Nairobi city was scheduled to host Magical Kenya Golf Championships and IAAF world u-20 championships events that were postponed due to the pandemic. It's beyond doubt that sports events have initially been associated with providing positive socioeconomic effects to the hosts (Nyikana \&Tichaawa 2018) but preventive actions by the different nations had hit hard the sports tourism's ability to provide socio economic well-being as a way of promoting sustainable sports tourism. The virtual events and social distancing has imposed negative impacts on the livelihood of people and host economies. This is a great challenge host cities or countries hence there is a need to come up with postCOVID-19 reviews of sports tourism and putting in place alternative future intervention and resilience measures for similar pandemics and other disasters. (Nhamo, Dube, Chikodzi (2020)

\subsection{Challenges of hosting sports tourism events}

Sports tourism events of all size are viewed as major catalysts of social and economic development in different parts of the world (OECD, 2010, Peric, 2018, Nyikaana, 2018, Sant, Misener \& Mason 2020) making hosting an increasingly important policy objectives of many governments. While some cities have withdrawn from bids in light of growing cost of competing for and staging events(Flyvberg,Stewart and Budzier,2016;Lauermann 2016), many other cities and regions continue to vie for hosting right(De Nooij and Van den Berg,2018;Solberg and Olderoien 2018).Additionally, other countries from Asia,Africa and the Latin America have emerged as new players in bidding for and hosting mega sports tourism events(Odhiambo 2015). On the other hand small events have also increasingly started gaining popularity and being sought by many cities(Gibson,Kaplanidou,\& Kang(2012);Njoroge et al 2017)

Despite this efforts, the process of bidding to host sports events has often been surrounded by various controversies, political machinations, promises of financial gains and economic growth (MacAloon,2016;Bason and Grix,2017).For instance, the recent granting of hosting rights to Qatar and China to host 2022 FIFA World Cup and 2022Winter Games respectively has been faced with alleged corruption, backhander and brown bag payment(Blake and Calvert 2015).There has been increasingly evidence that healthy competitions to host the Olympics is coming to an end. This has not only affected the bidding efforts for cities in developing countries but also has also locked out potential cities from bidding for hosting rights. The decline in bid cities has been also exacerbated with residents failing to support the idea (Grix, Brannagan, Wood and Wayne 2017). The residents are pivotal for the success of any sports events (Peric 2018,Herbold,2020).

Hosting of sports tourism events can bring about a number of challenges for the organizers. (Solberg and Olderoien (2018). Many of these incidents have been problematic for the organizers, the host cities, and the respective national federations (Andreff, 2012; Flyvbjerg \& Stewart, 2012).This research provides empirical evidence of such issues with reference to host city's efforts to host events which is currently very scant. Therefore the article will contribute to filling this gap by looking at this challenges and providing a holistic approach on how they can avoid them.

Visitor safety and security have become a requirement of many sports tourism destinations for the development of sustainable tourism .Many governments across the world are coming up with plans of enhancing a peaceful environment that assures visitors of their safety during the hosting of sports tourism events. Kenya has remained vulnerable due to political instabilities in countries like Somalia which have given rise to terror groups that have intensified security concerns during events. In addition, Community conflicts especially in pastoral regions have halted tourism activities in such regions. For example Turkana, Baringo, West Pokot and Laikipia Counties.

During the planning process, breaching of security issues may lead to high costs by the stakeholders in destinations that intend to host those events. This may lead to incidences of terrorism attacks as terrorists are attracted to sports tourism events that have high media publicity and many attendees who are crowded at the host venues .Political relations among nations may also motivate terrorists for example during Olympics in Munich city in 1972, Israel athletes were bombed, In 2009 there was a terrorist attack in Pakistan targeting Sri Lankan team during cricket competitions (Hinch and Higham, 2011). During AFCON tour in Angola in 2010, there was a terrorist attack on Togo national team who were going to the stadium for a match causing injuries to 9 people while 3 died, in Kampala in 2010 during IAAF championships, Al-shabaab militia made two explosions before the commencement of the event that claimed 64 lives (NCTC, 2011).Lastly, during the Boston Marathon in 2013, two explosives were witnessed that injured 144 people during the Marathon.

According to Gitare (2016), the high corruption rates in Kenya has impeded the successful hosting of the events. The embezzlement of funds meant of sports and infrastructural development has left the country with little or no sports facilities to bid for hosting sports events. This menace has weakened the capacity of cities to bid and has given the country a bad reputation. Nyanjom,(2010) also asserts that sports in Kenya has suffered for many 
years from corruption, mismanagement and political intrigue, resulting in the country's failure to make any significant impact in regional, continental or global competitions .

The success of sports events depend on their management. Most sports events are not properly managed. This could not be far from the fact that non-professional are in sports leadership positions. When a sports event is not properly managed and administered, it will not be interesting for sports tourists to attend and participate. Organizing sport tourism events, and mega-events in particular, requires the involvement of a diverse set of stakeholders directly and indirectly. Consequently, it is recommended that for the successful implementation of an organization's planning, implementation and/or outcomes of the event; stakeholders must have a mutual appreciation of interests of all persons or groups concerned(Swart,Tichaawa,Othy,Daniels 2018).

\subsection{Opportunities for hosting sports tourism events}

The host community's support play an important role in successful hosting of sports events in developing countries as they consider it as an opportunity to boost sustainable development and to enhance the status of the host communities. Sport tourism is continuously being utilized for the restructuring of both rural and urban local communities, which are in great need of regeneration in the emerging economies. Hemmonsbey \& Tichaawa, 2018; Homafar, Honari, Heidary, Heidary\& Emami 2011; Tichaawa \& Bob, 2015;Nyikana \&Tichaawa 2018 ).According to Njoroge et al. (2017), besides the much-publicized economic implications that are associated with sport tourism and events hosting, other lasting benefits also exist that can be leveraged for the long-term sustainable development of the communities. For example, sport tourism often leads to the fast-tracking of general infrastructure development, and to the creation of leisure and sporting facilities, which in turn, can attract investments in the lodging and catering industries for the local regions. (Bob \& Swart, 2010; Njoroge et al., 2017; Weed \& Bull, 2009). Such investments lead to growth of destinations and to the establishment of SMEs that enhance growth of local economies. Bouhaouala (2015) also notes that, hosting of sport tourism is seen as an important driver of growth, which is especially linked to socio-economic development opportunities as employment and business opportunity creation for the locals.

According to Radicchi (2013, sports tourism events are important resources for development in the context of emerging host cities. These events offer a platform for the host community to get employment, infrastructure development and boost in destination attractiveness. The extant literature has focused on impacts of sports tourism on host destinations. The current study will explore the opportunities that come with hosting of sports tourism events in emerging host cities showing a nexus between opportunities for hosting and sustainable sports tourism.

\subsection{Sports tourism events and socio-economic well-being of the host community}

Sports tourism events are now considered as the main attraction for lots of tourists both inbound and out-bound to travel to destinations that host sports events. The increased tourism activities have had great benefits to both the local community and the tourism sector as a whole (Homafar, Honari, Heidary, Heidary, \& Emami, 2011). Local and international sports tourists boost the growth of the local economy. The tourists boost the local economy by spending money on food, shopping, entertainment, accommodation and visiting other tourism sites in the host destination (Kim, Jun, Walker, \& Drane, 2014).

Nyikana \&Tichaawa (2018) also stated that sports events are effective vehicles for stimulating local economies through the provision of job opportunities, opening up local business opportunities and cultivating entrepreneurship spirit among the locals .For instance, Cameroon cities attract a huge number of informal businesses whenever sports events are hosted who utilize events as a driver for making economic gains through the selling of foods, drinks and sports related merchandise around stadia.

Mega events for instance the Olympics and FIFA world cup contain a renowned attractiveness, appeals to many people and international importance (Peric, Durkin \&Wise 2019; Hemmonsbey Tichaawa 2018). These events have led to huge global spectators, media attention; have reshaped global tourism trends, identified emerging sport tourism destinations in the world and leaving everlasting effects in the host countries (Peric 2018, Boonsiritomachai \&Phonthanukitithaworn 2019 ) who indicated that almost all sports tourism events have effects on local cities ,communities or countries that host them (Herbold et al 2020).

Major beneficiaries of these gains are the host regions, cities, states and nations that comprise of many different participants that work together to have successful events. Research efforts focusing on identifying benefits accrued by the host community after hosting sports tourism events have been scant (Boonsiritomachai \&Phonthanukitithaworn 2019,Kim et al 2014).Limited studies have been done which majorly dwelt on mega events . 
Research studies looking at the effects of sports tourism events on host communities within Kenyan and African contexts are scarce. A knowledge gap still exists for the need of an extension of research studies into sports events in Kenya. To fully comprehend the expected socio-economic effects associated with hosting events to host regions and communities, it was essential to review current literature available.

\section{Methodology}

\subsection{Study Design}

A cross-sectional research design was adopted in the study by use of quantitative and qualitative data. This research design encompassed the collection of data on a number of cases at a particular time in relation to two or more variables which are analyzed to come up with a degree of relationship among them. The design was suitable for this study because it gave the researcher a chance to gather information from the sample population selected and recorded the findings with no manipulation of the study variables (David and Sutton, 2004).In addition to that, the collection of data is completed at a particular point in time for all cases simultaneously (Bell, 2007). Quantitative and qualitative data of this study were collected at the same time from the host community and sports tourists. Qualitative data was gathered from the Ministry of Sports and Youth Affairs , Tourism and sports associations. Particularly, the research design will be used to give an overview of the importance of hosting sports tourism events on promoting the socio-economic well-being of the host community.

\subsection{Study Area}

The study area was Nairobi County which forms part of the forty seven devolved units and also Kenya's capital city .The county borders Kiambu, Machakos, Kajiado and Nakuru counties. It covers an area of $69603 \mathrm{~km} 2$.The County has nine sub counties .According to the KNBS, the county has a population of 4,004,097. The area was found suitable because it is among counties that have made significant steps in the development of sports tourism events both international, regional and local. The county is also well-endowed with sporting facilities like stadia that have continually allowed it to host sport tourism events for instance IAAF Championships in 2017.The County also houses all the headquarters of sports associations thus making it ideal to base on. Due to the wider scope of Nairobi County, the study focused on the sports associations employees, the host community (hoteliers, transport operators, and local traders within the stadia), and the three main stadia that frequently hosts events namely; Moi Sports Complex Kasarani, Nyayo stadium and City stadium.

\subsubsection{Moi International sports complex-Kasarani.}

The stadium was set up in 1987 when Kenya was selected as a candidate city to bid for hosting of the famous African Games which were to commence in the late 1980s. It has a capacity of accommodating sixty thousand attendees. It contains a number of distinguished visitors lounges and hospitality suites. It has media areas, shops, conference halls, restaurants and modernized changing rooms, offices, mini-shops, conference room and restaurants. To date, the stadium has hosted a number of spectacular events like IAAF World U-18, East Africa Military games, International derbies, African Volleyball Championships, Ice Stock Sports Africa, WRC Safari Rally and African Deaf Athletics Championships, and international rugby series.

\subsubsection{Nyayo stadium}

The stadium is found in Nairobi and built in 1983. It has a capacity of 30,000. It is mostly used for football sports activities especially the KPL games. It contains the following amenities; swimming pool, gym, handball and volleyball training pitches. It hosted the $4^{\text {th }}$ edition of All Africa Games in 1987, a mega sports event that gave Kenya international recognition due to the huge media publicity and promotion of tourism activities in the country. It was the host stadia for the African Athletics Championship in 2010 but Kenya got ripped off the rights of hosting because of lack of sufficient infrastructure and security issues

\subsubsection{Nairobi City stadium}

It's the oldest stadium in Kenya. It has hosted several sports events like football matches and athletic events. It has remained a major choice for hosting KPL championships. 


\subsection{Target population}

The population is defined as an entire number of people that a researcher is interested in and includes the total number of respondents, subjects, representation elements or environment. The target population for the study was the host community (local traders, transports operators, hoteliers), sports stakeholders (Sports associations, Ministry of Youth Affairs and Sports, Ministry of Wildlife and Tourism) and sports tourists within the three stadia namely; Moi Sports Complex Kasarani, Nyayo stadium and City stadium. According to KNBS (2019), there are a total of 1,099,453 people living in the purposively sampled constituencies where these stadia are found.

\subsection{Sampling size and procedure}

Sampling makes data collection faster and enhances homogeneity hence improves the data quality and accuracy (Kothari, 2004). A reconnaissance visit was conducted between $3^{\text {rd }}$ April, 2019 and $20^{\text {th }}$ May, 2019 at Sports Kenya Offices to determine the stadia that are active in hosting diversified events, the frequency of their hosting and the duration of their hosting. It was established that three stadia namely; Moi International Sports Complex, Nyayo stadium and Nairobi City stadium met this criteria and were found in Makadara, Lang'ata and Kasarani Constituencies respectively within Nairobi County thus were purposely be selected for the study.

\subsection{Sample size determination}

Mugenda and Mugenda (2003) defined sampling as the process of choosing a given number of respondents to represent a huge population from which they come from. The accuracy of estimation is influenced by the sample size (Yang et al., 2006). In scientific research, the determination of a sample size is a very important planning step of conducting research. Determination of sample size of this study was done by the use of statistical Equation 1 for larger proportions as suggested by Mugenda and Mugenda, (2003)

$\mathrm{n}=\frac{\mathrm{z}^{2} \mathrm{pq}}{d^{2}}$

Where;

$\mathrm{n}=$ the preferred sample size (for the target population more than 10000)

$\mathrm{z}=$ the normal standard deviation $(=1.96)$ at the desired confidence level

$\mathrm{p}=$ the section in the target population with an estimation of having features that are being measured $\mathrm{q}=1-\mathrm{p}$ thus $(1-0.5)-0.5$

$\mathrm{d}=$ statistical significance set level (accuracy $=0.05$ level desired)

Due to the lack of availability of estimates in the proportion of target population assumed to have the features of interest, $50 \%$ or 0.5 was applied in Equation 2.

$$
\begin{aligned}
& n=\frac{(1.96)^{2} \times(0.50) \times 0.50}{0.05^{2}} \\
& n=384
\end{aligned}
$$

Allowing a non-response rate of approximately 5\% of the sample, then 404 formed the sample size which was statistically significant for this study. 
3.6 Sample Frame

\begin{tabular}{|c|c|c|c|}
\hline CONSTITUENCY & Population size & $\begin{array}{l}\text { Sample } \\
\text { size }\end{array}$ & $n$ and $\%$ of $\mathrm{N}$ \\
\hline
\end{tabular}

$\mathbf{N} n$

$\begin{array}{lccc}\text { Kasarani } & 525,624 & 160 & \mathbf{1 6 0}(\mathbf{3 9 . 6 0 \%}) \\ \text { Lang'ata } & 355,188 & 149 & \mathbf{1 4 9 ( 3 6 . 9 \% )} \\ \text { Makadara } & 218,641 & 95 & \mathbf{9 5}(\mathbf{2 3 . 5 1 \% )}\end{array}$

\begin{tabular}{llll}
\hline Total & $1,099,453$ & 404 & $404(100 \%)$
\end{tabular}

Source: Kenya Population and Housing Census, (2019)

\subsection{Data Collection Instruments}

The study collected primary and secondary data. Questionnaires and key informant interviews were used to collect primary data. The following were the importance of using questionnaires; answers are given in respondents own words, they are free from biases, more adequate time of responding to the questions, they are convenient and huge numbers of respondents can be reached out within a short time thus yielding reliable information (Kothari,2004). Both close ended and open ended questions were included in the questionnaires.

The study also used key informant interviews to target the tourism stakeholders(,Sports associations, Ministry of Youth Affairs and Sports, Ministry of Wildlife and Tourism ).Interviews provided in-depth information and more reliable data (Mugenda and Mugenda, 2003).Collection of secondary data was accessed from journal articles, books, new papers, magazines, governments publications , reports and websites that helped get detailed information of literature that existed on hosting of sports tourism events on socio-economic wellbeing of the host community.

\subsection{Validity and Reliability of Research Instruments 3.8.1Validity}

It refers to the degree to which an instrument measures what it purports to measure Bryman \& Bell 2007).The questionnaire and the interview schedules were tested for both face and content. Content validity was done to ensure that the research instruments of the study had sufficient coverage of the content that they ought to have. Face validity on the other side was a subjective assessment based on expert opinion and getting their feedback on whether measures under the study were relevant in measuring what the researcher intended to measure. It entailed formatting the instrument and use of appropriate language use. Expert analysis was done by my two supervisors at the university for both content and face validity

\subsubsection{Reliability}

It refers to the extent to which a measure brings dependable outcomes or results. It also refers to the extent to which the scores lack random errors (Ary Jacobs, Razavieh, \& Sorensen 2006).It was measured by the reliability coefficient (Cronbach's alpha). Reliability for the host community and sports tourists' questionnaires were determined at the pretesting stage. Pretesting data was collected from five sports stakeholders, three sports tourists and three host communities, which was then put in SPSS. The analysis was computed from the software using Cronbach's Alpha model. A reliability coefficient of 0.877 was recorded. According to Cronbach and Shavelson (2004) the alpha should ideally be around 0.90 and never be below 0.70 . Hence the instrument was highly reliable.

\subsection{Data analysis}

After the completion of the data collection process, collected data under-went coding before being entered into the SPSS.Descriptive and inferential statistics were computed. Descriptive statistics was used to make a 
summary of the demographics of the sample population which included percentages and frequencies. The relationship between the independent and dependent variables were determined using simple correlation analysis. Thematic analysis was used to analyze qualitative data which involved reviewing the responses and making crucial generalizations based on certain themes obtained from the literature review. Presentation of results used tables.

\subsection{Ethical Considerations}

The researcher sought clearance from the Murang'a University and National Commission for Science Technology and Innovation that is mandated with issuing research permits in the country. The research also sought Informed consent from study participants, enhance the confidentiality of the information from participants and ensured accurate recording of data and presentation of results to curb plagiarism, falsification and fabrication of research findings. The researcher enhanced the anonymity of participants that were used in the study. The information from the study was clarified as only for academic purposes.

\section{Results and discussion}

\subsection{Response Rate}

A total of 404 questionnaires were issued to respondents and 373 filled questionnaires were returned representing $92.33 \%$ of the total questionnaires issued

\subsection{Demographic Information}

This presents the demographic information of respondents contacted during the study.

\begin{tabular}{lll}
\hline Characteristics & Frequency & Percentage \\
\hline Nationality & & \\
Kenyan & 261 & 70 \\
Non Kenyans & 112 & 30 \\
Total & $\mathbf{3 7 3}$ & $\mathbf{1 0 0}$ \\
\hline Gender & & \\
\hline Male & 213 & 57.1 \\
Female & 160 & 42.9 \\
Total & $\mathbf{3 7 3}$ & $\mathbf{1 0 0}$ \\
\hline Education & & \\
\hline Primary & 20 & 5.36 \\
High School & 41 & 10.99 \\
Tertiary/College & 137 & 36.7 \\
University & 175 & 46.9 \\
Total & $\mathbf{3 7 3}$ & $\mathbf{1 0 0}$ \\
\hline Age & & \\
\hline 18-24 & 25 & 9.7 \\
$36-45$ & 136 & 36.5 \\
$25-35$ & 176 & 47.1 \\
Above 46 & 36 & 6.7 \\
Total & $\mathbf{3 7 3}$ & $\mathbf{1 0 0}$ \\
\hline Marital Status & & $\mathbf{1 0 0}$ \\
\hline Married & $\mathbf{3 7 3}$ & \\
Single & & \\
Total & & \\
\hline Occupation/Profession & & \\
\hline Students & & \\
& & \\
\hline
\end{tabular}




\begin{tabular}{lll}
\hline Employed & 202 & 54.2 \\
Self Employed & 163 & 43.7 \\
Total & $\mathbf{3 7 3}$ & $\mathbf{1 0 0}$ \\
\hline Income & & \\
\hline Below20000 & 25 & 6.7 \\
$21000-30000$ & 201 & 53.9 \\
$31000-40000$ & 86 & 23.0 \\
$41000-$ above & 61 & 16.4 \\
Total & $\mathbf{3 7 3}$ & $\mathbf{1 0 0}$ \\
\hline
\end{tabular}

Table 1: Demographic Characteristics for sports tourism and host community

Nationality: The majority of the respondents were Kenyans as indicated by $70 \%$ of the respondents while $30 \%$ were non Kenyans. This segment was drawn from sports tourists from the Kenyan source markets namely; USA, Italy, Germany, China, UK, Uganda, Tanzania, Rwanda and South Africa .Sports tourism has a potential to promote domestic sports tourism market. This reduces overreliance on international tourists as well as promoting other tourism products. This finding was consisted with other similar study by Nyikana (2018) that asserts that, there is a huge domestic source markets for sports tourism events.

Gender: The majority of the sampled respondents were male as they constituted $57.1 \%$ while females were 42.9\%.Sevearl scholars have investigated hosts and tourists' gender differences influencing hosting and attendance of (Gibson et al 2012; Bason and Grix, 2017)

Education: The majority of the respondents had a university level of education as indicated by $46.9 \%$ while tertiary/college education holders were $36.7 \%$. High school/secondary level of education were $16.4 \%$ of the sampled respondents while $5.36 \%$ of them had a primary level of education. Level of education was found to interrelate with occupation and income. This finding is consistent with study conducted by Gitare (2016), Bennekon (2014) who have established that education, occupation and income tend to be highly interrelated in terms of travelling behaviour and patterns.

Age: In regard to age, the dominant age group was $25-35$ years with $47.2 \%$, the second one was between 36 45 years with $36.5 \%$, the third group was $18-24$ years with $9.7 \%$ while the last age group was between over 45 years of age with $6.7 \%$. This indicate that sports tourism events attract young adventurous segment of tourists who may be single or young couples with less family commitments hence more free time for leisure and travel.

Marital status: More than half of the sampled respondents were single as shown by $63.3 \%$ while $36.7 \%$ were married. This shows that most sports tourists have fewer family commitments and have enough time to travel .This implies that their length of stay is not limited by family, hence they are able to spend more on accommodation, transport,entertainments among others while in a host city.

Profession: $54.2 \%$ were employed while $43.7 \%$ were self-employed. Only $2.1 \%$ of the sample respondents were students.

Income: majority of the sampled respondents earned between Ksh 21,000 and 30,000 as indicated by 53.9\% while those who earned between 31,000 and 40,000 were $23.1 \%$. The results further revealed that $16.4 \%$ of the respondents earned above 41,000 and only $6.7 \%$ were earning less than 20,000. Majority earning less than 20000 were students, who don't have a disposable income

\subsection{Challenges of Hosting Sports Tourism Events}

In order to ascertain the challenges that were more likely to affect the hosting of sports tourism events in Nairobi, the respondents were asked to indicate their opinions in relation to this in a Likert scale format where (1): unlikely (2): least likely (3): fairly likely (4): likely and (5): most likely. The results are as shown in table 2 below 


\begin{tabular}{|c|c|c|c|c|c|c|}
\hline Challenge & 1 & 2 & 3 & 4 & 5 & Mean \\
\hline $\begin{array}{l}\text { Numerous natural } \\
\text { calamities }\end{array}$ & $14.7 \%(55)$ & $15 \%(56)$ & $63.3 \%(236)$ & $3.5 \%(13)$ & $3.5 \%(13)$ & 2.65 \\
\hline $\begin{array}{l}\text { Security and safety } \\
\text { issues. }\end{array}$ & $5.9 \%(22)$ & $8.3 \%(31)$ & $13.4 \%(50)$ & $46.9 \%(175)$ & $25.5 \%(95)$ & 3.78 \\
\hline Lack of facilities & $3.2 \%(12)$ & $9.4 \%(35)$ & $18 \%(67)$ & $46.1 \%(172)$ & $23.3 \%(87)$ & 3.77 \\
\hline $\begin{array}{lr}\text { Poor } & \text { planning of } \\
\text { sports } & \text { tourism } \\
\text { events } & \end{array}$ & $3.2 \%(12)$ & $16.6 \%(62)$ & $16.4 \%(61)$ & $23.1 \%(86)$ & $40.8 \%(152)$ & 3.82 \\
\hline Policy issues & $3.5 \%(13)$ & $3.5 \%(13)$ & $17.2 \%(64)$ & $26.3 \%(98)$ & $49.6 \%(185)$ & 4.15 \\
\hline
\end{tabular}

\section{Table 2: Challenges of Hosting Sports Tourism Events}

From Table 2, the majority of the sampled respondents indicated numerous natural calamities are fairly likely to affect the successful hosting of sport tourism events in Kenya as indicated by $63.3 \%(236)$. The results further revealed that $3.5 \%$ (13) of the sampled respondents indicated that numerous natural calamities are likely and the same also indicated that they are most likely to affect the successful hosting of sports tourism events in Kenya. A mean of 2.65 indicated that generally, numerous natural calamities are fairly likely affect successful hosting of sports tourism events in Kenya.

The results further revealed that security and safety issues are likely to affect the successful hosting of sport tourism event in Kenya as indicated by a mean of 3.78. This was further supported by majority of the respondents $46.9 \%$ (175) indicated it is likely to affect the successful hosting of sports tourism events in Kenya

Availability of facilities is also a challenge as shown by $46.1 \%(172)$ and $23.3 \%(87)$ who indicated they are likely and most likely respectively to affect successful hosting of sport tourism event in Kenya. A mean of 3.77 implies that lack of facilities is likely to affect successful hosting of sport tourism event in Kenya. Poor planning of sports tourism events is likely to affect successful hosting of sport tourism event in Kenya as indicated by a mean of 3.82. Lastly, $26.3 \%(98)$ and $49.6 \%$ ( 185) of the sampled respondents indicated that policy issues are likely and most likely respectively to affect successful hosting of sport tourism event in Kenya. A mean of 4.15 indicated that generally, policy issues are likely to affect successful hosting of sport tourism event in Kenya.

\subsection{Opportunities for Hosting Sports Tourism Events}

The study established that majority of the sampled respondents confirmed that sports tourism events provide an avenue for the development of other tourism activities in the county. Further, the respondents were asked to indicate how accurate the following opportunities provide sustainable sports tourism development on a Likert scale of $5=$ strongly agree $4=$ agree $3=$ Neutral $2=$ Disagree $1=$ strongly disagree. 


\begin{tabular}{|c|c|c|c|c|c|c|}
\hline Indicator & 1 & 2 & 3 & 4 & 5 & Mean \\
\hline $\begin{array}{l}\text { It provides an opportunity to } \\
\text { diversify tourism products }\end{array}$ & $6.7 \%(25)$ & $9.9 \%(37)$ & $12.9 \%(48)$ & $40.8 \%(152)$ & $29.8 \%(111)$ & 3.77 \\
\hline $\begin{array}{l}\text { It provides an opportunity to } \\
\text { market the destination }\end{array}$ & $3.5 \%(13)$ & $3.2 \%(12)$ & $6.7 \%(25)$ & $43.2 \%(161)$ & $43.4 \%(162)$ & 4.2 \\
\hline $\begin{array}{l}\text { It provides an opportunity to visit } \\
\text { other attractions within the } \\
\text { destination }\end{array}$ & $3.5 \%(13)$ & $10.2 \%(38)$ & $13.1 \%(49)$ & $50.1 \%(187)$ & $23.1 \%(86)$ & 3.79 \\
\hline $\begin{array}{l}\text { Provides an opportunity for } \\
\text { promoting domestic tourism }\end{array}$ & $3.5 \%(13)$ & $11.5 \%(43)$ & $14.7 \%(55)$ & $34 \%(127)$ & $36.2 \%(135)$ & 3.88 \\
\hline
\end{tabular}

\section{Table 3: Opportunities of Hosting Sports Tourism Events}

From Table 3, $40.8 \%(152)$ and $29.8 \%(111)$ of the sampled respondents agreed and strongly agreed respectively that hosting sports tourism events provides an opportunity to diversify tourism products. A mean of 3.77 implies that hosting sports tourism events provides an opportunity to diversify tourism products. The results further revealed that $43.2 \%$ ( 161) and $43.4 \%$ ( 162) agreed and strongly agreed respectively that hosting sports tourism events provides an opportunity to market the destination. A mean of 4.20 postulates that hosting sports tourism events provide an opportunity to market the destination.

The study established that the majority of the respondents $50.1 \%(187)$ agreed that hosting sports tourism events provided an opportunity to visit other attractions within the destination and a further $23.1 \%$ (86) supported this assertion. A mean of 3.79 suggests that hosting sport tourism events provide an opportunity to visit other attractions within the destination. Lastly, $34 \%$ (127) and $36.2 \%$ (135) of the sampled respondents agreed and strongly agreed respectively that hosting sports tourism events provide an opportunity for promoting domestic tourism.

This result may be explained by the fact that, as an extended form of host community participation in tourism, sports tourism empowers the host community to earn an income from tourism directly while providing them with the opportunities to establish their businesses and employment opportunities. This finding has important implications for the Ministry of Tourism to craft policies and legislations to create an enabling environment to encourage the growth and development of the sports tourism sub-sector in a sustainable manner.

\subsection{Linear Regression for Hosting of Sports Tourism Events Variables}

The study also conducted a simple linear regression involving Challenges and opportunities for hosting sports tourism events against Socio-Economic Wellbeing. The results are as shown in table 4.

\begin{tabular}{|c|c|c|c|c|c|c|c|c|c|}
\hline \multirow[t]{2}{*}{ Model } & \multirow[t]{2}{*}{$\mathbf{R}$} & \multirow{2}{*}{$\begin{array}{l}\text { R } \\
\text { Square }\end{array}$} & \multirow{2}{*}{$\begin{array}{l}\text { Adjusted R } \\
\text { Square }\end{array}$} & \multirow{2}{*}{$\begin{array}{l}\text { Std. Error of } \\
\text { the Estimate }\end{array}$} & \multicolumn{5}{|c|}{ Change Statistics } \\
\hline & & & & & $\begin{array}{l}\text { R Square } \\
\text { Change }\end{array}$ & F Change & df1 & df 2 & $\begin{array}{ll}\text { Sig. F } & \text { F } \\
\text { Change } & \end{array}$ \\
\hline 1 & $.576^{\mathrm{a}}$ & .332 & .330 & .31683 & .332 & 184.083 & 1 & 371 & $.576^{\mathrm{a}}$ \\
\hline
\end{tabular}

a. Predictors: (Constant), Challenges and Opportunities

Table 4.: Multiple Regression for Hosting of Sports Tourism Events Variables 
The simple regression analysis in table 4 revealed that challenges and opportunities for hosting sports tourism events account for up to $33.2 \%\left(\mathrm{R}^{2}=0.332\right)$ of change in the socio-economic wellbeing to the host community. This implies that challenges and opportunities for hosting sports tourism events are significant predicators of socio-economic wellbeing. Opportunities for hosting such as diversifying tourism products, marketing of the destination, visiting other attractions within the destination and promoting domestic tourism would result into increase in socio-economic well-being to the host community thus leading to sustainable development. On the other hand, proper disaster preparedness of natural calamities, improvement in security and safety issues, proper planning of sports events and proper policy formulation and implementation would increase socio-economic wellbeing.

\subsection{Thematic Analysis}

To establish the challenges and opportunities for hosting sports tourism events 4.6.1. Challenges for hosting sports tourism events in Nairobi

Numerous challenges were cited as likely to affect the hosting of the sports tourism events by the sports tourism stakeholders

"There have been rows of wrangles in sport leadership, Sub-standardized facilities, insufficient manpower to man the sports docket and lack of a proper policy framework in place to propel the development of different forms of sports tourism each year". Moreover one respondent was of the believe that Nairobi County is a hub of so many activities, sports being one of them

"Security is one of the core issues affecting Nairobi County that most likely lead to cancelling or losing bids to host events. The current terrorism attacks targeting tourism and hospitality establishments, should be enough reason to prioritize security when hosting events in Nairobi. On the other hand, Nairobi has limited stadia that can comfortably host mega events like the Olympics and the FIFA World cup "

Another respondent lamented that

"Poor management of sports associations and clubs has led to the inability of the sports associations to perfectly engage in bidding for some of the events to be held in Nairobi. Furthermore more on the challenges likely to affect the hosting of sports tourism in Nairobi, one interviewee indicated that

"Poor planning of events have resulted in low attendances, interrupted duration and low spending during sports tourism hence has directly affected the economic returns expected from such events. Corruption has also contributed negatively to the hosting of events. The fund meant for sports and infrastructural development are mismanaged and sometimes embezzled by Kenyans. Embezzlement of sports fund has left the country with little or no sports facilities, making it difficult to comfortably bid and host sports competitions for sport tourists to attend. Therefore, the country can't boast of world class sport facilities not because of lack of resources but due to corruption especially on the part of the political leaders who mismanage the resources."

With regard to the effect of these challenges on the socioeconomic wellbeing of the host community, the respondents felt that

"The ability of a county to host an event should be in its capacity to maximize the benefits and minimize the risks or challenges involved. Therefore, challenges such as policy issues, facilities, manpower skills, security and planning have in the recent past made Kenya to be scrapped off the rights to host some spectacular events such as CAF championships"

Therefore, the government should try to fight corruption to build public confidence in investing in sports tourism, improve sports facilities in Nairobi and outside Nairobi, revamp more security measures to ensure safety during events and lastly engage in more marketing activities to make Nairobi a sports tourism destination regionally and internationally. This will boost its image as a destination in hosting events and therefore be able to competitively bid to host events that may bring socioeconomic development to the country and its hosts.

\subsubsection{Opportunities for hosting sports tourism in Nairobi}

The respondents expressed their perspective that hosting of sports tourism events provides a unique opportunity for host cities to offer growth opportunities for the respective local economies.

"Sports events are part of a broader strategy aimed at raising the profile of a city, they contribute to the reimaging of the destination and gives a chance to a host city to open up linkages globally. Sports tourism events provide opportunities for a country and host cities to engage in the high-profile promotion of their products on a global scale, for the development of international standard sporting facilities and related infrastructure upgrades, and for the gaining of a head start for the bidding for other major events. In addition to that It's a vehicle for promoting other tourism sites in the destination, where by sports participants may visit these site before during or after the events.", Stated the respondent. 
Furthermore it provides an opportunity for a county to diversify its tourism products to curb seasonality that comes as a result of too much reliance on one tourism product.

Based on thow opportunities for sports tourism can boost socioeconomic wellbeing of the host respondents indicated that;

"Sport tourism events in the country, are seen by counties as being an important vehicle for improving the quality of life of the host communities by attracting visitors, who then contribute to the economic well-being of the locals. Sports tourism events provide a vital role in enhancing national and local tourism offerings, while also transforming destinations to become desirable event-driven economies."

The findings on this variable concur with the findings by Tichaawa and Nyikana (2018), Knott and Hemmonsbey, (2015) Nyikana and Tichaawa (2018. This finding however, differs from the findings of Solberg and Olderoien, (2018), who found a negative effect of challenges and opportunities for hosting on the socioeconomic wellbeing.

This thematic analysis agrees with the quantitative results that challenges and opportunities positively affect the socio-economic wellbeing of the host community.

\subsection{Conclusion}

This article provides useful insights into the sports tourism events is one of the dynamic sub-sector in sports tourism known for creating socio-economic changes across the local communities. Its role in diversifying the tourism products, provision of employment, and establishment of sports facilities, cultural exchanges, and environmental protection ultimately contributes to sustainable development.

Based on the findings of this study, key challenges that face the hosting of sports tourism events in emerging destinations like Kenya were highlighted. These included; lack of planning, policy issues, security, lack of facilities and poor manpower skills. Tourism can achieve the intended socio economic developments if it's planned well. Strategic planning will enable a destination to focus on various niches of travel that are capable of attracting tourists. Sustainable planning of sports events will incorporate the hosts that can enable them to jobs and expand businesses before and during the events. This has not been put in place during the past events that has affected the perceptions of the hosts on sports tourism event. Lack of sports facilities that meet international standard was also a major setback to the city's efforts to host large events. Before bidding, the bidding cities must ensure they have the required facility to host that particular event successfully. The embezzlement of funds has affected the development of stadia and related facilities.

Lack of policies that deal with sports tourism has affected Nairobi's efforts to host events. The authorities at the county and national governments need to craft realistic policies that can spur sports tourism developments like marketing the country as a sports destination. Understanding the link between tourism and sports policy is vital for sustainable sports tourism development, therefore policy makers should but this in place to be able to reap more benefits and minimize possible costs.

Security is very crucial during events, amidst the terrorist attacks, the country ought to tighten their security belts. The recent terrorists' attacks has affected the tourists' flows in the country. Therefore, sports stakeholders should enhance security to during events to portray a good image of the country as a host. Tourist safety is paramount and cannot be compromised.

On the other hand, the findings were evident that sports tourism comes with lots of opportunities for the host destinations. Sports events can be used to revamp the domestic tourism market, in the wake of the Covid 19 pandemic, most tourism destinations are relying on this segment of travel due to travel guidelines and lock downs that were issued during the break of the pandemic. Secondly, sports tourism can be used to diversify the tourism products in the country. Kenya has been known for safari and beach tourism for a long time, different destinations are coming up with different niche products to expand their source markets. Sports tourism is a niche that can be used to attract sports enthusiasts during hosting of events. Several events have got major legacies for host cities. Thirdly, hosting sports events provides a chance for host cities to be recognized globally and its image uplifted. Other tourism products get to be known during events as supplementary products. Finally, hosting sports tourism events offers the locals a chance to sell their merchandise and employment opportunities. This helps to improve the quality of their livelihoods.

The above emerging challenges and opportunities show the neglect on sports tourism sector at the same time presents the ways sports tourism can be used as a tool for sustainable tourism development in a destination. In a nut shell, sports tourism is untapped niche that when properly planned can yield lots of benefits to the host community in both the urban and rural destinations. 
References

Andreff, W. (2012).The winner's curse: Why is the cost of mega sports events so often underestimated? In Maenning.W and Zimbalist, A (Eds).International handbook on the economics of mega sporting events (pp.37-69).Cheltenham,UK/Northamptom,USA:Edward Elgar.

Auer, C. (2014). Libya Out as Host of African Cup of Nations. [Online] Guardian Liberty Voice. Available at: http://guardianlv.com/2014/08/libya-out-as-host-of-african-cup-of-nations/ [Accessed 2 Nov. 2020]

Bason, T., \& Grix, J. (2018). Planning to fail? Leveraging the Olympic bid. Marketing Intelligence \& Planning, $36(1), 138-151$

Bennekom, L. (2014). Aligning destination image, sport event image and image fit: An exploration of the interrelationship between cognitive and affective images among spectators of Dutch Running Events. [Master's thesis, University of Utrecht

Blake, H. and Calvert, J. (2015), The Ugly Game: The Qatari Plot to Buy the World Cup. Simon \& Schuster UK, London

Bryman, A. \& Bell, E. (2007). Business Research Methods (2nd.ed). New York, USA: Oxford University Press.

Cooper, D. R., \& Schindler, P. (2006). Business Research Methods. (9th, Ed.) New York, NY: McGraw Hill Irwin.

Chalip, L. (2015). From legacy to leverage. Leveraging Legacies from Sports Mega-Events: Concepts and Cases; Grix, J., Ed.; Palgrave Macmillan: London, UK, 2015; pp. 2-12

Cronbach, L.J. \& Shavelson R.J. (2004). My Current Thoughts on Coefficient Alpha and Successor Procedures. Educational and Psychological Measurement, 64(3), 391-418.

De Nooij, M., \& Van den Berg, M. (2018). The bidding Paradox: Why politicians favor hosting mega sports events despite the bleak economic prospects. Journal of Sport and Social Issues, 42(1), 68-92

Galvani, A., Lew, A. , \& Perez, M. S. (2020). COVID-19 is expanding global consciousness and the sustainability of travel and tourism. Tourism Geographies, 22 (3), 567-576. https://doi.org/10.1080/14616688.2020.1760924

GoK. (2008). The Kenya Vision 2030, Nairobi: Government Printer

Gibson, H. J., Kaplanidou, K., \& Kang, S. J. (2012). Small-scale event sport tourism: A case study in sustainable tourism. Sport Management Review, 15(2), 160-170.

Grix, J. (2012).Image'leveraging and sports mega-events: Germany and the 2006 FIFA World Cup. Journal of Sport \& Tourism, Vol.17 No.4, pp.289-312.

Grix, J., Brannagan, P. M., Wood, H. and Wynne, C. (2017).State strategies for leveraging sports mega-events: unpacking the concept of 'legacy. International Journal of Sport Policy and Politics, Vol.9 No.2, pp.203-218

Flyvbjerg, B., Stewart, A., \& Budzier, A. (2016). The Oxford Olympics study 2016: Cost and cost

Overrun at the games.

Herbold, V.; Thees, H.; Philipp, J. (2020). The Host Community and Its Role in Sports Tourism—Exploring an Emerging Research Field. Sustainability

Homafar, F., Honari, H., Heidary, A., Heidary, T., Emami, A. (2011). The role of sport tourism in employment, income and economic development. Journal of Hospitality Management and Tourism, 2(3), 34-37

Kenya Institute of Public Policy Research (2018), “Kenya Economic Report. Boosting investment for delivery of Kenya vision 2030”, Nairobi: KIPPRA.

Kenya Law, (2013). Kenya Sports Act, 2013[Online] Available at: http://kenyalaw.org/k1/fileadmin/pdfdownloads/Acts/SportsActNo25of2013.PDF [Accessed: 17 Dec 2020].

King, N. (2009). Sport Policy and Governance: Local Perspectives, Butterworth-Heinemann.

Kothari, C. R. (2004). Research Methodology: Methods and Techniques (2nd ed.). New Delhi: New Age International Publishers.

Knott, B. \& Hemmonsbey, J. (2015).The strategic value of sport for an African city brand. African Journal for Physical, Health Education, Recreation and Dance, 21 (1), 191-204

KTB Report, (2018) Tourism sector performance reports.www.tourism.go.ke

Lauermann, J. (2016). Boston's Olympic bid and the evolving urban politics of event-led development. Urban Geography,37(2), 313-321

MacAloon, J. J. (2016) .Agenda 2020 and the Olympic Movement. Sport in Society: Cultures, Commerce, Media, Politics, Vol.19 No.6, pp.767-785

McCloy, C. (2009). Canada Hosts the World: An Examination of the First Federal Sport Hosting Policy (1967). The International Journal of the History of Sport Vol. 26: 9, 1155-1170. 
Mugenda, O., \& Mugenda, A. (2003). Research Methods: Quantitative and Qualitative Approaches. Nairobi: Acts Press.

Nhamo, R, Dube, K., Chikodzi, d. (2020) Impact of COVID-19 on the Global Sporting Industry and Related Tourism: Counting the Cost of COVID-19 on the Global Tourism Industry (pp.225-249) Publisher: Springer, Cham. DOI: 10.1007/978-3-030-56231-1 10

Njoroge, J., Atieno, L. \& Nascimento, D. (2017). Sports tourism and perceived socio-economic impact in Kenya: The case of Machakos County. Tourism and Hospitality Management, Vol. 23, No. 2, pp. 195-217.

Njoroge, J.M., Akama, J.S. and Buyeke, E.(2015), “Challenges to sustainable sports tourism development in a non-metropolitan region in Kenya: A case of Iten township', in René van der Duim, Guido Klep and Konstantinidou, E.(2015) Sustainability, tourism and Africa: A natural link, Thematic proceedings of ATLAS Africa Conferences, Vol. 9, pp. 18-32.

Nyikana, S., Tichaawa, T. \& Swart, K. (2018). Sport, tourism and mega-event impacts on host cities: a case study of the 2010 FIFA World Cup in Port Elizabeth. African Journal for Physical, Health Education, Recreation and Dance, 20(2:1), 548-556.

Organisation of Economic Co-operation and Development, (OECD). (2010). Local development benefits from staging global events: Achieving the local development legacy from 2012. A peer review of the Olympic and Paralympic legacy for East London proposed by the Department of Community and Local Government. United Kingdom. Retrieved from http://www.oecd.org/cfe/leed/46207013.pdf

Obonyo, M. O. (2013). Financing Sports in Kenya: A Case of Kenya Basketball Federation, Prime Journal of Business Administration and Management (BAM) ISSN: 2251-1261. Vol. 3:8, 1161-1170,

Peric, M. (2018) Estimating the Perceived Socio-Economic Impacts of Hosting Large-Scale Sport Tourism Events. Social Sciences. , 7,(176).

Radicchi, E. (2013). Tourism and sport: Strategic synergies to enhance the sustainable development of a local context. Physical Culture and Sport Studies and Research, Vol. 57, pp. 44-57.

Swart, K., Tichaawa, T., Othy, J. D. O. \& Daniels, T. (2018). Stakeholder perspectives of sport tourism development in Gabon: A case study of the Africa Cup of Nations. Euro Economica, 1(37):177-189.

Santos, M.A, Misener.L \& Daniel S. Mason (2020): Leveraging sport events for tourism gain in host cities: a regime perspective, Journal of Sport \& Tourism, DOI:10.1080/14775085.2019.1711444

Solberg, H. A., \& Olderøien, L. (2018). The challenges of hosting major events owned by international federations: A case study of the 2014 Chess Olympics. Event Management, 22(4), 595-60

Tichaawa, T.M, \& Bob, U. (2015).Leveraging mega-events beyond the host nation: a case study of the 2010 FIFA World Cup African Legacy Programme in Cameroon and Nigeria. Leisure Studies, 34(6), 742757

Weed, M. and Bull, C. 2009. Sports tourism: Participants, policy and providers, Oxford: ButterworthHeinemann

World Bank, (2018) Kenya - Poverty incidences in Kenya decline significantly but unlikely to be eradicated by 2030 Washington, DC: World Available at: http://documents.worldbank.org/curated/en/2018/04/16350074/kenya-tourism-polishing-jewel (accessed 10 January 2020)

UNWTO. UNWTO; Madrid, Spain: 2020. UNWTO World Tourism Barometer (Vol. 18, Issue 2, May 2020).Available at http://publications.unwto.org/publication/worldtourism barometer 2020. 